\title{
Survey on the socio-economic profile of fish farmers in Shivamogga district of Karnataka
}

Received: 23 July, 2020

Accepted: 13 August, 2020

Published: 14 August, 2020

*Corresponding author: Shashikanth H Majagi, Department of Studies in Zoology, Vijaynagara Sri Krishnadevaraya University, Ballari-583105, Karnataka, India, E-mail: smajgi@rediffmail.com

Keywords: Socioeconomic; Shivmogga; Farmers; Karnataka; Pisciculture

https://www.peertechz.com

\section{Check for updates}

\author{
Somashekar DS ${ }^{1}$ and Shashikanth H Majagi2* \\ ${ }^{1}$ PG Studies in Zoology, IDSG Government College, Chikkamagaluru-577102, Karnataka, India \\ ${ }^{2}$ Department of Studies in Zoology, Vijaynagara Sri Krishnadevaraya University, Ballari-583105, \\ Karnataka, India
}

\begin{abstract}
An investigation was carried out to unearth the socio-economic profile of fish farmers in Shivamogga district, Karnataka. A total of 70 fish farmers of 51 villages selected randomly and they were personally interviewed through a pre tested structural schedule. Certain parameters related to their socio-economic status namely, family size, literacy status, age, basic amenities, occupation, package and practices of fish culture, operational economics have been studied and presented. Further the study emphasized that the Socio-economic profiles play a pivotal role in the upliftment of fish farming activities.
\end{abstract}

\section{Introduction}

Fisheries sector plays a predominant role not only in terms of contributing to our food basket, but also acts as a cheap source of animal protein supporting our rural health, resource potential and employment opportunities. Fisheries sector, which plays a very important role in socio-economic development of the country, has been recognized as a powerful income and employment generator as it stimulates the growth of a number of subsidiary industries and is a source of cheap and nutritious food besides being a valuable foreign exchange earner. Most importantly, fishery is a source of livelihood for a large section of the economically backward population.

Fish farmers are the backbone of fish culture and they were play a very important role in fish culture. The livestock production potential is based on the socio economic factors of the farmer [1], which play a vital role in the adoption of improved technologies [2]. The socio-economic background of people determines, to a great extent, their habits and attitudes, which shape their perceptions on entrepreneur activities.

The investigations on socio-economic status of fish community and fish farmers have been carried out in different states of India by some workers [3-12]. Fish culture in Karnataka can be a district sector in view of its vast resource potential, employment opportunities, income generation and source of animal protein in diet. In spite of having about 6.31 lakh hectares inland water resources in the form of rivers, reservoirs, ponds and tanks, at present production is only 86,262 Metric tons [13] and there is considerable further scope to increase inland fish production. The state has about 2.93 lakh hectares of ponds and tanks suitable for fish culture. However, the information on the level of basic infrastructure, techniques used while culturing the fishes and socio-economic conditions of fish farmers in general and Shimoga district of Karnataka in particular is scanty. Hence, an attempt was undertaken to unearth the socio-economic profile of fish farmers of the study area, diversified areas of interest were focused under the field survey.

\section{Materials and methods}

The study area is located in between $12^{\circ} 54^{\prime}$ to $14^{\circ} 39^{\prime}$ North altitude and $74^{\circ} 21^{\prime}$ East longitude. A survey was conducted for the period from 2014 to 2015 . A total of 70 fish farmers from 50 Villages belonging to 7 Taluks (Shikaripura, Shimoga, Sagar, Bhadravathi, Thirthahalli, Hosanagara and 
Soraba) of Shivamogga district were selected randomly and they were interviewed at their pond sites to collect the first hand information with a pre-tested structural questionnaire. Following factors viz., related to their socio-economic status namely, family size, literacy status, age, basic amenities, occupation, package and practices of fish culture, operational economics have been studied and the data were calculated on percent basis.

\section{Results and discussion}

Table 1 shows some important socio-economic factors of fish farmers in Shivamogga district of Karnataka. It was observed that medium sized fish culture families are more (35.4\%) when compared to small sized (34.2\%) and large sized families $(30.4 \%)$. About $49 \%$ of the fish farmers of Shimoga district were middle-aged whereas the young aged fish culturists are $35.9 \%$ and about $15.1 \%$ were old aged fish culturists. When compare to these age groups middle-aged group is higher and they can actively involve in pisciculture. The literacy of fish farmers in Shimoga district is good about $44.5 \%$ of the fish farmers are matriculated and below matriculated are $31.8 \%$. About $18 \%$ of people were under graduated; however, only $5.7 \%$ were graduated. Since majority of the fish farmers are educated in this region, they can be trained easily about the latest technology, so that, the fish production can be enhanced. In the present study fish farmers taking pisciculture as part

Table 1: Socioeconomic profile of fish farmers in Shivamogga district.

\section{SI. No. $\quad$ Factors}

Percentage

Family size
a. Small $(<4)$
b. Medium $(<6)$
c. Large $(>6)$
Age group
a. Young age
b. Middle age
c. Old age
Education

b. Matriculation to College level

c. Graduation

Type of occupation (Pisciculture)

b. Full time

Experience in pisciculture

b. More than 5 years

Fish seed stocking rate per hectare

\section{Type of carp culture}

a. Composite

7

$$
\text { b. Mono }
$$

c. Integrated

d. Non-integrated

48.9

Utilization of supplementary fish feed

b. Non-users time and full time occupation were estimated as $86.6 \%$ and $13.4 \%$ respectively. Hence, majority of farmers are practicing fish culture for their secondary source of income. The study reveals that majority of the farmers $(43.1 \%)$ had low level of farming experience followed by medium level (34.1\%) only a few farmers $(22.8 \%)$ had high level of experience in fisheries (Table 1). This has indicated that farmers are having moderate experience in fish culture.

The species mix in fish seed and stocking rate are two important determinants in economics of pisciculture i.e., cost of production and level of output. Majority of farmers follow medium stocking density ( $48.9 \%$ ) that is about $8000 /$ hectare. Remaining $27.6 \%$ and $23.5 \%$ of farmers stock fish seed in low and high stocking densities respectively. It was interesting to note that, the fish production was directly related to stocking density of fish seed i.e., the maximum fish production was observed in optimum stocking of fish seed.

In the project area, majority of the farmers (98.10\%) commonly practices composite carp culture which include major corps viz. Catla, Rohu, Mrigala, Common carp species and only (1.90\%) of farmer prefer monocarp culture. The study confirms that, $35.8 \%$ fish farmers practices the integrated fish culture and remaining $64.2 \%$ of fish farmers practices non integrated fish culture. It was observed that the farmers who are engaged in integrated fish culture were getting more profit compared to fisheries alone. The approach of integrated system is much profitable and also sustainable for smallscale aquaculture practices for maximum utilization of land. Integrated farming has been justified as more productive and efficient approach in many parts of the world [14-17].

As far as our survey is concerned majority (82.8\%) of fish farmers used supplementary feeding for fish culture while $17.2 \%$ of fish farmers are not using supplementary feed which play a vital role in fast growth of fishes. With regard to the knowledge of fish farmers on fish diseases nearly $36.5 \%$ responded that, they were knowing the same and remaining (63.5\%) admitted that they were not having awareness regarding fish diseases. However the reports on incidences of fish diseases in our study area is less.

The operational economics of fish production of our study area has been analyzed (Table 2). The total yearly operation cost incurred in fish production includes, rent of ponds, assets like net, coracle, expenses on finger-lings, manures, feed etc. per hectare of fish production. In our study area average cost of fish production per hectare were Rs. 41,100 constituting variable and fixed expenses. The average net profit per hectare over yearly operational cost was about Rs. 22,150. Based on these finding it implies that returns to capital are about $53.8 \%$, and it proves that it was favorable for investment in aquaculture.

The survey clearly shows that, the socio-economic status of fish farmers of this area is in moderate condition and therefore, an effective step should be taken to encourage the fish farmers for successful utilization of aqua-wealth of this region for their development and also inland fisheries. 
Table 2: Operational economics of pisciculture in study area.

\begin{tabular}{|c|c|c|}
\hline 1 & Average fish production (kg/ha) & 2,250 \\
\hline 2 & Total yearly operational cost (Rs) & 41,100 \\
\hline 3 & Total returns (Rs) & 67,800 \\
\hline 4 & Gross profit (Rs) & 26,700 \\
\hline 5 & Net profit (Rs)/Year & 22,150 \\
\hline 6 & $\begin{array}{c}\text { Returns to capital (\%) } \\
\text { (NP/total yearly operational cost) }\end{array}$ \\
\hline 7 & $\begin{array}{c}\text { Output-Input ratio (\%) } \\
\text { (Over yearly operation cost) }\end{array}$ & 164.2 \\
\hline
\end{tabular}

Note: This economy will be changeable according to the time, region and market

\section{Conclusion}

The study emphasized the socio-economic profiles play a pivotal role in the upliftment of fish farming activities. The socio-economic status of fish farmers of this area is in moderate condition. Based on these finding it implies that returns to capital is about $53.8 \%$. The maximum fish production was observed in optimum stocking of fish seed. It was observed that the farmers who are engaged in integrated fish culture were getting more profit compared to fisheries alone and it proves that it was favorable for investment in aquaculture.

\section{References}

1. Das SK, (1997) Socio-economic factors affecting the adaptation of livestock technologies by the farmers in West Bengal. Indian Vet J 74: 233-236.

2. Basavarajappa S, Somashekar DS, Raghu KS, Rajashekara GB (2002) Socio economic profile of the silk worm (Bombayx mori L.) seed rearers in malnad of Karnataka, India. Ad Bios Sci 21: 1-10.

3. Dalai SK, Das S (1992) Economic analysis of fish production under extensive aquaculture practice in Ganjan district of Orissa. J Sea Food Export 24: 21-23.

4. Singh RKP, Prasad KK (1991) Economics of fish production and marketing in Samastipur, Bihar. J Ecobiol 16: 20-22.
5. Kalita K, Kalita B (1994) Culture fishery in Nagaon district of Assam. Fishing chimes 13: 25-27.

6. Roy AK, Sahoo KN, Saradh KP, Saha GS (2001) Aquaculture in Kolleru lake for socio-economic development. Environment and Ecology 19: 927-931.

7. Veerappa Gowda HS, (2002) States of Fisheries development in Karnataka Fishing Chimes 22: 12-14.

8. Kumar A, Sharma OP (2001) Socio-Economic status of fishermen in relation to fisheries of Lake Jaisamand. Fishing Chimes 20: 45-47.

9. Boarch BK, Sharma M (2002) Evaluation of socio-economic status of fishermen community in middle sonitpur district of Assam. Environment and Ecology 20: 351-356.

10. Manna K, Chatterjee NR, Manohar S, Goswami A (2004) Survey of the Socioeconomic profiles of fishermen engaged in Beel. Environment and Ecology 22: 245-246.

11. Bhuyan, PC, Naik D (2004) Economic analysis of fish culture practice in Dibrugarh, Assam. J Ecobiol 16: 345-349.

12. Prabhudev KN, Sudhakar AC, Jayaprakash GN (2004) Rice-based fish culture is a boon in northern Karnataka. Fishing chimes 23: 10-11.

13. Statistical Bulletin of fisheries (2002-2003) Department of fisheries. Bangalore, Government of Karnataka 14-18.

14. Woynarovich $E$ (1979) Utilization of piggery wastes in fish ponds. Environment and Ecology 22: 454-458.

15. Hopkins KD, Cruz EM, Hopkins M, Chang KC (1980) Optimum manure loading rates in tropical fresh water fish ponds receiving untreated piggery wastes. ICLARM Tech Rep 2: 15-29. Link: https://bit.ly/2FextoD

16. Ayyaan S, Kumar K, Jana JK (1988) Integrated fish farming practices and potential. Fishing Chimes 18: 15-18.

17. Upadhaya SN, Dutta A (1991) A study on socio-economic conditions and fish culture practices of rural fish culturists in Assam. Fishing chimes 21: 18-21.

Discover a bigger Impact and Visibility of your article publication with

\section{Peertechz Publications}

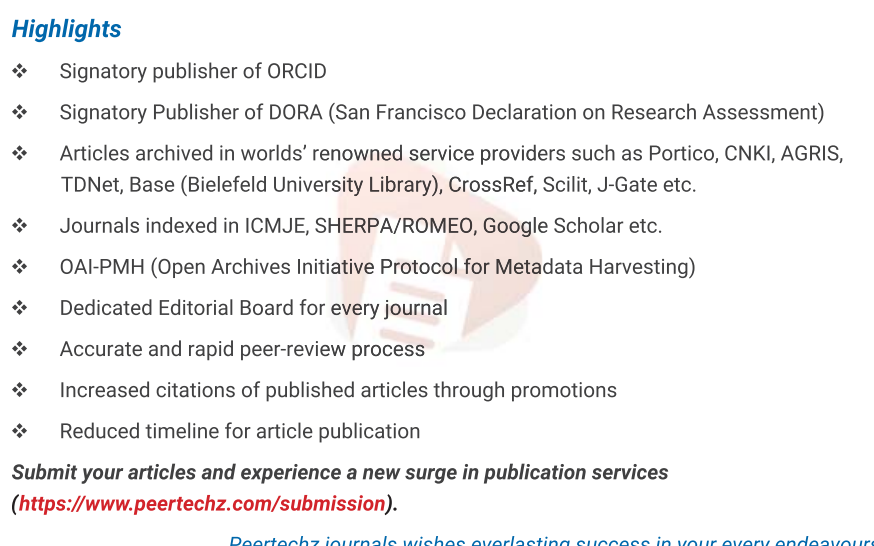

Peertechz journals wishes everlasting success in your every endeavours.

Copyright: @ 2020 Somashekar DS, et al. This is an open-access article distributed under the terms of the Creative Commons Attribution License, which permits unrestricted use, distribution, and reproduction in any medium, provided the original author and source are credited. 